\title{
PERBANDINGAN KEKERASAN BAHAN GLASS IONOMER CEMENT YANG DIRENDAM ANTARA OBAT KUMUR BERALKOHOL DENGAN OBAT KUMUR BEBAS ALKOHOL
}

\author{
Farid Yuristiawan $^{1}$, Gunawan $^{2}$, Detty Iryani $^{3}$ \\ ${ }^{1}$ Mahasiswa Fakultas Kedokteran Gigi, Universitas Andalas, Indonesia. \\ ${ }^{2}$ Dosen Fakultas Kedokteran Gigi, Universitas Andalas, Indonesia. \\ ${ }^{3}$ Dosen Fakultas Kedokteran, Universitas Andalas, Padang, Sumatera Barat, Indonesia.
}

\begin{abstract}
Glass ionomer cement is one of the filling material that often used on the field of dentistry because it is relatively less expensive and mostly available. It's existence in the mouth makes it susceptible to any substance that comes into mouth one of them is mouthwash which is a solution that used for many purposes such as antiseptic, astrigent, to prevent caries and bad breath. The aim of this research is to know the comparison of surface hardness of glass ionomer cement which soaked in alcohol containing mouthwash and alcohol-free mouthwash. This research is a laboratoric experimental type study. Sampels made from GC FUJI IX GP EXTRA for as much as 30 sampels were made and then soaked in artificial saliva for the first 24 hours inside incubator which temperature and humidity were controlled. Sampels then divided into 3 groups. First group will be soaked in alcohol containing mouthwash, second group will be soaked alcoholfree mouthwash and control group will be soaked in artificial saliva for 6 hours inside incubator. Listerine is the mouthwash that was used on this research and surface hardness was examined using Vickers Hardness Tester. The result of this research shows mean value for surface hardness of the first group is 16.36 VHN, $24.04 \mathrm{VHN}$ for second group, and $43.60 \mathrm{VHN}$ for control group. The result one way ANOVA with post hoc Bonferroni comparing test show significant results $p=0.00$. In Conclusion there are significant differences of surface hardness between each groups, which surface hardness of the first group is lower than the second group, and both surface hardness of the first and second group are lowered than control group $(p=0.00)$.

Key words : Glass Ionomer Cement, Mouthwash, Surface Hardness
\end{abstract}

Affiliasi penulis: Fakultas Kedokteran Gigi,

Universitas Andalas, Padang, Sumatera Barat, Indonesia

Korespondensi: Farid yuristiawan e-mail: farid.yuristiawan@ gmail.com

\section{PENDAHULUAN}

Glass ionomer cement (GIC) adalah salah satu bahan restorasi yang digunakan dalam dunia kedokteran gigi, pertama kali dikembangkan oleh Wilson dan Kent pada tahun 1971 pada saat mereka mengembangkan semen silikat karena tingginya permintaan untuk material alternatif pengganti amalgam dalam beberapa dekade terakhir. Glass ionomer cement terdiri dari bubuk semen kaca fluoroaluminosilikat dan larutan asam poliakrilat dimana kombinasi dari kedua bahan ini dapat menggabungkan kekerasan, kepadatan, dan kemampuan untuk melepaskan fluoride dari bubuk kaca silikat engan biokompatibilitas dan sifat adhesif dari asam poliakrilat. ${ }^{1,2}$

Glass ionomer cement banyak dipilih oleh dokter gigi sebagai bahan restorasi karena memiliki potensi sebagai antikariogenik dengan melepaskan ion flour yang lebih banyak dibandingkan dengan bahan restorasi lain seperti 
komposit, mempunyai estetik yang baik dibandingkan bahan restorasi berbahan metal, biokompatibel dengan rongga mulut, memiliki koefisien ekspansi termal yang sebanding dengan struktur gigi, dan kemampuan untuk melekat secara kimiawi dengan baik pada dentin dan enamel gigi. ${ }^{3,4}$

Keberadaan glass ionomer cement sebagai bahan restorasi di dalam rongga mulut menyebabkan seringnya glass ionomer cement tersebut berkontak dengan berbagai macam zat dan komponen yang masuk ke dalam rongga mulut, salah satunya adalah obat kumur.

Berdasarkan aturan pakai yang tercantum dalam kemasan obat kumur yang beredar di pasaran, yaitu berkumur setiap hari dengan frekuensi 2 kali sehari selama 30 detik, mengindikasikan bahwa obat kumur berkontak dengan gigi dan mulut selama 6 jam pertahun. Beberapa orang bahkan berkumur menggunakan obat kumur dengan frekuensi hingga 6 kali per harinya, ini menunjukan bahwa bahan restorasi yang terdapat dalam mulut berkontak dalam waktu yang cukup lama dengan obat kumur. ${ }^{5}$

Menurut hasil penelitian Gurgan, $\mathrm{dkk}^{6}$ tentang pengaruh obat kumur yang mengandung akohol dan obat kumur yang bebas alkohol terhadap kekerasan beberapa bahan restorasi, menunjukan hasil bahwa kedua obat kumur baik yang beralkohol maupun bebas alkohol dapat mempengaruhi kekerasan dari beberapa bahan restorasi seperti resin komposit dan glass ionomer cement, hal ini sejalan dengan Pendapat $\mathrm{M}$ roeroe $\mathrm{dkk}^{7}$, keberadaan alkohol sebagai pelarut dalam minuman dapat mengurangi kekerasan permukaan dari bahan restorasi glass ionomer cement. namun menurut Awliya, $\mathrm{dkk}^{8}$ tidak hanya unsur alkohol dalam obat kumur yang dapat mempengaruhi kekerasan dari bahan restorasi. Unsur lain seperti air yang merupakan komponen utama penyusun obat kumur selain dapat membantu dalam proses reaksi pengerasan glass ionomer cement, juga dapat melarutkan ion - ion penyusun dari glass ionomer cement itu sendiri. ${ }^{6-10}$

Kekerasan permukaan merupakan salah satu sifat yang terpenting dalam bahan restorasi, yaitu merupakan ketahanan suatu material terhadap indentasi, yang akan berhubungan dengan kekuatan tekan dan ketahanan suatu material terhadap abrasi, dimana makin tinggi kekerasan permukaan suatu material maka semakin tinggi juga kemampuannya untuk bertahan dari abrasi. $^{8,11}$ Tujuan Penelitian ini adalah untuk mengetahui perbandingan kekerasan permukaan glass ionomer cement yang direndam dalam obat kumur 
yang mengandung alkohol dan obat kumur tanpa kandungan alkohol.

\section{METODE PENELITIAN}

$\begin{array}{rcc}\text { Desain } & \text { Penelitian ini } & \text { adalah } \\ \text { eksperimental } & \text { laboratoris } & \text { dengan } \\ \text { menggunakan } & \text { Post test only } & \text { control }\end{array}$ group design. Penelitian dilaksanakan di Laboratorium Kimia Koordinasi Perguruan Tinggi Swasta Wilayah X dan Laboratorium Metalurgi Program Studi Teknik Mesin Fakultas Teknik Universitas Andalas, dilaksanakan mulai dari bulan Februari hingga Maret 2016. Sampel penelitian adalah hasil cetakan tumpatan glass ionomer cement konvensional dengan merek dagang GC Fuji IX GP EXTRA yang berbentuk cakram dengan tebal $2 \mathrm{~mm}$ dan diameter $6 \mathrm{~mm}$, disesuaikan dengan ukuran rata-rata ketebalan enamel dan lebar mesial-distal gigi pada umumnya. ${ }^{12}$ Sampel dibuat sesuai dengan criteria inklusi sejumlah 30 buah. $^{13}$

Gambar 1. Dimensi Sampel Glasss Ionomer Cement

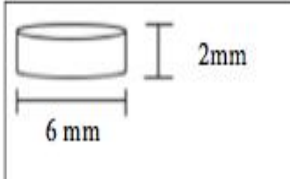

Keseluruhan sampel yang berjumlah 30 buah yang dibagi menjadi 3 kelompok perlakuan, yaitu 10 buah sampel direndam dalam saliva buatan, 10 buah sampel direndam dalam obat kumur beralkohol, dan 10 buah sampel direndam dalam obat kumur tanpa kandungan alkohol, sebelumnya seluruh sampel yang akan direndam dalam obat kumur direndam oleh saliva buatan di dalam inkubator dengan suhu $37^{\circ} \mathrm{C}$ dan kelembapan relatif sebesar $94-97 \%$ selama 24 jam. Ini bertujuan untuk menyamakan keadaan seluruh sampel dengan kondisi suhu dan kelembapan rongga mulut bagian posterior dan menstabilisasi proses reaksi asam basa pada tahap pengerasan glass ionomer cement agar tidak terjadi kekurangan intake air. ${ }^{14,15}$

Setiap kelompok sampel kemudian direndam selama 6 jam sesuai dengan masing masing kelompok perlakuan di dalam inkubator dengan suhu $37^{\circ} \mathrm{C}$ dan kelembapan relatif sebesar 94-97\%, yang setara dengan penggunaan selama 1 tahun dengan ketentuan berkumur selama 30 detik dengan frekuensi 2 kali setiap hari sesuai dengan aturan pakai yang dianjurkan dalam kemasan obat kumur.

Masing-masing sampel dari tiap kelompok perlakuan kemudian diangkat lalu dibuatkan 3 titik pengukuran. Titik pengukuran terletak segaris sejajar dengan garis diameter sampel dengan titik paling ujung berjarak masing masing $1 \mathrm{~mm}$ dari tepi sampel. Pengukuran kekerasan permukaan dilakukan pada tiap-tiap sampel pada kelompok perlakuan dengan 
alat penguji kekerasan Vickers Hardness Tester dengan memberikan tekanan sebesar 1 Kgf selama 10-15 detik. Begitu seterusnya hingga didapatkan hasil untuk seluruh sampel pada tiap kelompok perlakuan. Data yang diperoleh kemudian dianalisis dengan metode univariat Saphiro Wilk, dan metode bivariat one way ANOVA. ${ }^{16}$

\section{HASIL PENELITIAN}

Analisis univariat dilakukan pada masing masing kelompok perlakuan dengan uji normalitas Saphiro Wilk untuk mengetahui apakah data terdistribusi secara normal. Hasil uji normalitas dari setiap kelompok data memiliki nilai $p$ yang lebih besar dari $0,05(\mathrm{p}>0,05)$ yang berarti data pada tiap kelompok perlakuan terdistribusi normal. Nilai $\mathrm{p}=0.68$ bagi kelompok perendaman dalam obat kumur beralkohol, nilai $\mathrm{p}=0.73$ bagi kelompok perendaman dalam obat kumur beralkohol dan nilai $\mathrm{p}=0.24$ bagi kelompok kontrol.

Selanjutnya untuk mengetahui apakah terdapat perbedaan yang signifikan antar tiap kelompok perlakuan, maka dilakukan uji statistik one way ANOVA dengan tingkat kemaknaan $(\mathrm{p} \leq 0,05)$. Dari hasil uji one way ANOVA tersebut didapatkan nilai $\mathrm{p}=0.00(\mathrm{p} \leq 0.05)$ yang berarti terdapat perbedaan yang signifikan pada tiap kelompok perlakuan, seperti yang ditunjukan oleh tabel 1 .

Tabel 1. Perbedaan kekerasan glass ionomer cement setelah dilakukan perendaman dengan uji one way ANOVA.

\begin{tabular}{cccc}
\hline $\begin{array}{c}\text { Kelompok } \\
\text { Perlakuan }\end{array}$ & Rasta-rata & SD & P \\
\hline $\begin{array}{c}\text { Obatkumur } \\
\text { Berakohol }\end{array}$ & 16.36 VHN & 2.47 & \\
Obatkumur bebas & 24.04 VHN & 3.22 & 0.00 \\
alkohol & 43.60 VHN & 4.28 & \\
Kontrol & & \\
\hline
\end{tabular}

Setelah dilakukan uji one way ANOVA selanjutnya dilakukan uji multiple comparisons untuk menguji apakah terdapat perbedaan antar masing masing kelompok perlakuan dengan menggunakan metode post hoc Bonferroni. Hasil uji multiple comparisons menunjukan bahwa terdapat perbedaan yang signifikan antara kelompok kontrol dengan kelompok perendaman dalam obat kumur beralkohol dan kelompok perendaman dalam obat kumur bebas alkohol.

Perbedaan yang signifikan juga didapatkan pada kelompok perendaman dalam obat kumur beralkohol dengan perendaman dalam obat kumur bebas alkohol, seperti yang digambarkan oleh tabel 2, dimana nilai $\mathrm{p}$ yang signifikan adalah $\mathrm{p} \leq 0.05$.

Nilai p yang didapatkan dari hasil multiple comparison dengan metode post hoc bonferroni menunjukan bahwa 
terdapat perbedaan yang signifikan antar

Tabel 2. Perbandingan kekerasan rata-rata glass ionomercement setelah perendaman masing-masing kelompok

\begin{tabular}{|c|c|c|c|}
\hline Kilompor & $\begin{array}{l}\text { Obathumy } \\
\text { Beralkono }\end{array}$ & $\begin{array}{c}\text { Ohatunut beres } \\
\text { allohol }\end{array}$ & Kontrol \\
\hline $\begin{array}{l}\text { Obat humi: } \\
\text { Barat lohod }\end{array}$ & & & $p=100$ \\
\hline $\begin{array}{c}\text { Ohat woni batas } \\
\text { allowo }\end{array}$ & $p=0.00$ & & \\
\hline Kontol & $p=000$ & & \\
\hline
\end{tabular}

\section{PEMBAHASAN}

Penelitian ini menunjukan bahwa

nilai kekerasan permukaan rata-rata bahan restorasi glass ionomer cement pada kelompok yang direndam dalam obat kumur beralkohol adalah sebesar 16.36 VHN. Nilai ini lebih rendah apabila dibandingkan dengan kelompok kontrol dan kelompok yang direndam dalam obat kumur bebas alkohol pada waktu perendaman yang sama.

Nilai kekerasan permukaan yang lebih rendah pada kelompok yang direndam dalam obat kumur beralkohol dapat disebabkan oleh kandungan alkohol dalam obat kumur yang mampu melarutkan ion-ion pembentuk ikatan silang yang terdapat dalam glass ionomer cement seperti ion aluminium dan ion kalsium, dan juga unsur lain seperti natrium dan fluoride yang terdapat pada glass ionomer cement. ${ }^{8}$ tiap kelompok perlakuan $(\mathrm{p} \leq 0.05)$.

perlakuan dengan Multiple Comparisons Metode Post Hoc Bonferroni

Hasil penelitian ini sejalan dengan hasil penelitian sebelumnya yang dilakukan oleh Awliya $\mathrm{dkk}^{8}$ dan Lohbauer $^{15}$ dimana ion aluminium dan kalsium yang terdapat pada glass ionomer cement ikut terlarut dikarenakan ion tersebut dapat berikatan dengan hidroksil pada unsur alkohol. Sifat kelarutan ini akan berhubungan dengan kekerasan permukaan dari glass ionomer cement tersebut, dimana semakin besar terjadinya kelarutan maka semakin rendah kekerasan permukaan dari glass ionomer cement tersebut. ${ }^{8,15}$

Hasil penelitian ini tidak sejalan dengan hasil penelitian yang dilakukan oleh Roeroe $\mathrm{dkk}^{7}$ dimana keberadaan unsur alkohol dalam minuman yang dikonsumsi dapat menambah kekuatan tekan bahan restorasi glass ionomer cement yang berhubungan langsung dengan kekerasan permukaan dari bahan tersebut. hal tersebut dapat disebabkan oleh pembuatan sampel menggunakan cetakan yang bentuknya tidak silinder sempurna, dan kandungan komposisi selain alkohol dari minuman tersebut. ${ }^{9}$

Hasil Penelitian ini juga menunjukan bahwa nilai kekerasan permukaan rata-rata bahan restorasi glass 
ionomer cement pada kelompok yang direndam dalam obat kumur bebas alkohol adalah sebesar 24.04 VHN. Nilai ini lebih rendah apabila dibandingkan dengan kelompok kontrol yang direndam dalam saliva buatan dan lebih tinggi apabila dibandingkan dengan kelompok yang direndam dalam obat kumur beralkohol pada waktu perendaman yang sama, selisih nilai kekerasan permukaan yang terjadi cukup besar apabila kedua kelompok perendaman baik dalam obat kumur beralkohol, maupun obat kumur bebas alkohol apabila dibandingkan dengan kelompok kontrol yang direndam dalam saliva buatan. ${ }^{12}$

Nilai kekerasan permukaan yang lebih rendah pada kelompok yang direndam dalam obat kumur bebas alkohol apabila dibandingkan dengan kelompok kontrol dapat disebabkan oleh kandungan air yang tinggi dalam obat kumur tersebut, dimana baik dalam obat kumur yang mengandung alkohol maupun bebas alkohol terdapat kandungan air yang tinggi hingga $90 \%$ dari keseluruhan obat kumur.

Hal ini sejalan dengan penelitian yang dilakukan oleh Gemalmaz dkk ${ }^{10}$ dimana keberadaan unsur air dapat melarutkan garam yang terbentuk pada reaksi asam dan basa pada saat pengerasan glass ionomer cement. Unsur air juga dapat melarutkan ion aluminium yang berfungsi sebagai pembentuk matriks ikatan silang dalam glass ionomer cement dikarenakan ion aluminium terlambat untuk mengalami reaksi menggantikan ion kalsium sebagai pembentuk ikatan silang pada reaksi pengerasan glass ionomer cement, selain itu keberadaan unsur air dalam obat kumur juga dapat mengerosi permukaan bahan restorasi glass ionomer cement sehingga menyebabkan terjadinya hidrolisis. ${ }^{8,10}$

Keberadaan unsur air selain dapat melarutkan ion pembentuk ikatan silang pada glass ionomer cement, juga dapat membantu proses pengerasan dari glass ionomer cement sendiri, dimana unsur air dapat mencegah terbentuknya keretakan pada permukaan glass ionomer cement akibat dehidrasi pada saat pengerasan. ${ }^{15}$ Perbedaan kekerasan permukaan rata rata yang signifikan pada kelompok glass ionomer cement yang direndam dalam obat kumur beralkohol dan obat kumur bebas alkohol dapat disebabkan oleh kandungan alkohol yang berada pada obat kumur tersebut, dimana obat kumur memiliki kandungan alkohol yang cukup tinggi hingga 20\% dari keseluruhan obat kumur. ${ }^{17}$ Hal ini menyebabkan kekerasan permukaan yang lebih rendah pada kelompok yang 
direndam dalam obat kumur beralkohol dibandingkan dengan obat kumur bebas alkohol. Nilai rata-rata hasil pengukuran menggambarkan bahwa terdapat nilai rata-rata kekerasan permukaan yang lebih rendah pada kelompok obat kumur yang beralkohol dan obat kumur bebas alkohol apabila dibandingkan dengan kelompok kontrol yang direndam dalam saliva buatan dengan waktu perendaman selama 6 jam.

\section{KESIMPULAN}

Hasil penelitian ini menunjukan bahwa baik obat kumur beralkohol dan obat kumur bebas alkohol dapat mempengaruhi kekerasan dari bahan restorasi glass ionomer cement, dimana nilai kekerasan permukaan glass ionomer cement yang direndam dalam obat kumur beralkohol leih rendah apabila dibandingkan dengan nilai kekerasan permukaan glass ionomer cement yang direndam obat kumur bebas alcohol.

\section{KEPUSTAKAAN}

1. Krämer N, Frankenberger R. (2001). Clinical performance of a condensable metal-reinforced glass ionomer cement in primary molars. British Dental Journal; 189: 317-321.

2. Fransisconi L.F, Scaffa P.M.C, Barros V.R.S, Coutinho. M, Fransisconi P.A.S. (2009). Glass ionomer cements and their role in the restoration of non-carious cervical lesions. J Appl Oral Sci; 17(5): 364-9.

3. Yilmas Y, Eyuboglu O, Kocogullari M.E, Belduz N. (2006). A one-year clinical evaluation of a high viscousity Glass Ionomer Cements on primary molars. The
Journal of Contemporary Dental Practice. Volume 7. No 1.

4. Anggraini R, Yogyarti S, Harijanto E. (2011). Kekerasan permukaan semen ionomer kaca konvensional dan modifikasi resin setelah perendaman dalam minuman cola. Material Dental Journal, Vol. 2. No. 1 January-June 2011: 26-30.

5. Moran J.M (2000). Chemical Plaque Control - Prevention for the masses. Periodontology. Vol 1b 1997, 119117. Denmark.

6. Gurgan S, Onen A, Koprulu H. (1997). In vitro effects of alcohol-containing and alcohol free mouthrinses on some restorative materials. Journal of Oral Rehabilitation 24: 244-246.

7. Roeroe V.M (2015). Gambaran kekuatan tekan bahan tumpatan semen ionomer kaca yang direndam dalam minuman beralkohol. Jurnal e-GiGi (eG), Volume 3,.

8. Awliya W.Y.(2009). The Effect Of Mouthrinses on Surface Hardness And Weight Change Of Some Esthetic Restorative Material. Department of Restorative Dental Science, College of Dentistry, King Saud University Riyadh, Saudi Arabia.

9. Akande O.O, Alada A.R.A, Aderinokun G.A. Ige A.O. (2004). Efficacy of different brands of mouthrinses on oral bacterial load count in healthy adults. African Journal of Biomedical Research, Vol 7; 125-128.

10. Gemalmaz D, Yoruc B, Ozcan, Alkumru. (1998). Effect of early water contact on solubility of glass ionomer luting cements. Journal of Prosthetic Dentistry. Vol 80.

11. Anusavice K.J (2004). Phillips' science of dental materials. Edisi X. Alih bahasa. Budiman JA, Purwoko S. EGC. Jakarta. pp. 444-469.

12. Nelson S.J, Ash M.M. (2014). Wheeler's Dental Anatomy, Physiology. Saunders. Elsevier. St Louis. Missouri. pp.1-19.

13. Hidayat A.A. (2011). Metode Penelitian Keperawatan dan Teknik Analisis Data. Edisi Pertama. Salemba Medika. Jakarta.

14. Mathias P, Rocha V, Saraiva L, Cavalcanti A.N, Azevedo J, Paulillo L.A. (2010). Intraoral environment conditions and their influence on marginal leakage in 
composite resin restorations. Acta Odontol Latinoam. Vol 23. No. 2. 105-110.

15. Lohbauer U. (2009). Dental Glass Ionomer Cements as Permanent Filling Materials? -Properties, Limitations and Future Trends. Materials, 3, 76-96; doi:10.3390/ma3010076.

16. Dahlan S. (2011). Statistik Untuk Kedokteran dan Kesehatan Edisi 5. Salemba Medika. Jakarta. pp. 2-26.

17. Schmolka I.R, (1984). Mouthwash Composition. Patent no US44776107A. 